\title{
Challenging Biblical Fundamentalism by Seeking the Influence of the Synagogue in the Formation of the Synoptic Gospels $^{1}$
}

\author{
J S Spong ${ }^{2}$ \\ (University of South Africa)
}

\begin{abstract}
Challenging Biblical Fundamentalism by Seeking the Influence of the Synagogue in the Formation of the Synoptic Gospels
\end{abstract}

Taking cues from Michael Goulder's book Midrash and Lection in Matthew the author argues a case for taking the context of the synagogue seriously as the place were the story about Jesus was recalled and passed on for a minimum of forty years. By using primarily the gospel Mark as frame of reference he illustrates how this context left its mark not only on the gospel of Mark but on the other two synoptic gospels as well. In the synagogue the Hebrew Scriptures were "wrapped around" the story of Jesus. Readers should therefore not read the gospels as historical accounts of his life but as interpretations of his life and acts. A historical-literal reading of the synoptic gospels distorts the message which the authors tried to convey about Jesus.

\section{INTRODUCTION}

I am passionate about the necessity of reforming Christianity. I rejoice that I find a similar desire in South Africa. My passion for a new reformation comes out of two things: first, I am committed to Jesus Christ as the center of my faith tradition and second, I am disillusioned with what is currently happening in the world of institutional Christian religion.

I look at the Roman Catholic Church, my sister communion, and find it marching headlong into yesterday. One cannot chart the

1 The author read this paper on Sunday 28 October 2007 at the University of South Africa. It was deliberately planned to coincide with Protestant churches celebration of the Reformation on the last Sunday of October. It was decided to keep to the wording of the paper as it was delivered on that day and not to adjust it to a more elevated style normally required for scholarly articles.

2 Research Associate, Department of Old Testament \& Ancient Near Eastern Studies and Department of New Testament, University of South Africa. 
path this church has taken in its journey during the last sixty years, from the great ecumenical Pope, John XXIII, in successive backward steps to Paul VI, John Paul I, and John Paul II to Benedict XVI and not grieve for a church in full retreat from reality. This is a church that has effectively silenced its scholars ${ }^{3}$, that pretends that it possesses unchallengeable truth in propositional form and that reveals in a thousand ways that it no longer lives in this century ${ }^{4}$.

I look at what is happening in Protestantism. Its evangelical side is becoming more and more fundamentalist, more and more strident and angry, and more and more disturbing about the way it uses the Bible to enforce its dated prejudices ${ }^{5}$.

The moderate or progressive side of Protestantism is at the same time shrinking into non-existence as people drop out of all religious involvement because less and less of it sounds credible. They become citizens of the secular society. The broad, highly educated Protestant churches that we once called "mainline" are quite frankly withering on the vine. The more these traditionalists and evangelicals define Christianity, the more those who are not comfortable with that definition join the "Church Alumni Association". They generally are not bold enough to challenge the traditionalists and the fundamentalists openly, nor are they generally informed enough to articulate new possibilities courageously. The days of hazy, weak commitment to a socially acceptable religious pattern are over.

I look at my own Anglican Communion, torn as it is over the issue of homosexuality, about which its leaders seem to know almost

3 I refer to its removal of Hans Küng from his position as Catholic theologian in Tübingen; its harassment of the Dutch theologian Edward Schillebeeckx; its removal from his tenured position with the Catholic University in Washington, D C of Charles Curran, and its silencing of Matthew Fox.

4 Benedict XVI recently reasserted that there is only one true religion, Christianity, and only one true expression of Christianity, the Roman Catholic Church. This same mentality also permeates his book Jesus of Nazareth.

5 American evangelicals like Albert Mohler, Pat Robertson and the late Jerry Falwell were steadfast in claiming inerrancy for every word of the Bible and then using those claims to justify an extremely right-wing political agenda, including being anti-woman, anti-homosexual, pro-corporal punishment, procapital punishment and even pro-war. 
nothing ${ }^{6}$. There is little to inspire anyone about a church battling to preserve its ill-informed homophobia. Somehow, the news has not gotten to Anglican leaders that no reputable person in the scientific or medical community believes that sexual orientation is something human beings choose, and so, in either profound ignorance or in weakness of character, various representatives of this church's leadership tear apart this once broad and lively communion, using the literal Bible as their weapon of choice.

What does one do then, when one is deeply drawn to Jesus and simultaneously deeply repelled by what is happening to religion in the organized Christian Church? My personal response to this dilemma was to take a page from Dietrich Bonhoeffer's haunting call for the development of a religionless Christianity that emanated from his Nazi prison cell in 1944 (Bonhoeffer 1971). Bonhoeffer was searching for a Christianity that could transcend and escape the boundaries of religion. He was the inspiration for my book Jesus for the Non-Religious (Spong 2007). It was and is my intention in that book to lift Jesus out of the religious patterns of the past and to project Him and his message beyond the confines of organized religion that threatens today to destroy Him.

\section{A RADICAL CHANGE}

Traditional Christianity is dying primarily because it still pretends that it can ignore the thought revolution of the last 500 years. That revolution, I would argue, began with Copernicus in the $16^{\text {th }}$ century and was carried on by Kepler and Galileo in the $17^{\text {th }}$ century, who introduced us to the vastness of both time and space (Scholder 1990). It was successful in destroying the three-tiered universe on the basis of which the Bible was written. This new angle of vision made stories like the Tower of Babel in Genesis, the pouring out of the sky of heavenly bread called manna on the starving children of Israel during the wilderness years of the Exodus, the star in the heavens that first announced Jesus' birth and then traveled so slowly that wise men could keep up with it and the story of Jesus' cosmic ascension to return to the God above the sky, totally meaningless in any literal reading.

6 A recent report to the Church of England from the Royal College of Psychiatrists on Human Sexuality made this very clear. 
That revolution in our thinking about the universe was followed by the work of Isaac Newton, especially in his masterpiece entitled The Principia, where, building on the work of Galileo, he rendered nonsensical many of the things the Bible called miracles (Olson 2004). Supernatural intervention does not fit well with natural law and so this thought challenged both the way Christians defined God and the way Christians understood prayer.

Next Charles Darwin's insights radically challenged the way Christians have told the Jesus story. Darwin suggested that we were not created instantaneously in God-like perfection, only to fall into sin by a willful act of disobedience, as the book of Genesis, read literally, seems to suggest. We were created as single cells and then evolved over billions of years into increasing complexity, into consciousness and even into self-consciousness. There was no fall, as Christians have maintained for centuries, not even metaphorically. There was no original perfection from which to sink into original sin and thus there is no need for an intervening divine rescue to restore us to that status which we have never possessed. We rather are creatures evolving toward a destiny we have never achieved, a new and whole humanity. This insight makes the Protestant "mantra", "Jesus died for my sins" and the Catholic understanding of the Mass as the liturgical re-enactment of "the sacrifice of the cross" where the consequences of the fall were overcome meaningless and all but nonsensical.

\section{THE BIBLE AND CHRISTIANITY IN THE TWENTY- FIRST CENTURY}

In this presentation I will focus on what I see as the crucial issue facing Christianity in the $21^{\text {st }}$ century. My aim is to challenge, quite specifically, the way Christians continue to use the Bible in both public discourse and in church liturgies. Almost every part of the Christian Church claims that in some sense its theology and its ethics are "Bible based". Many of those making this claim actually persist in referring to the Bible as "The Word of God". They condemn anyone who is not willing to treat their literally understood Bible as the final authority in every debate. They even attack and seek to marginalize those biblical scholars who refuse to countenance their improper use of scripture. This has produced the strange anomaly where Christian scholars are called heretics by Christian people. Can anyone imagine such an attitude in the field of medicine or any other branch of human knowledge? Sadly, in these activities the literal- 
minded Christians assume that they are the ones who are defending the scriptures and, even more startling, that they are even reading the gospels in the way the gospel writers intended them to be read. I submit that each of these claims is significantly uninformed and profoundly ignorant. These religious spokespersons have done what so many religious people do: they have confused their opinions with facts. The task of biblical scholarship is not to debate opinions, but to establish facts. So let me lay my groundwork by stating some biblical facts that are no longer debated in the larger world of biblical scholarship.

By comparing available secular records with biblical traditions, we can now establish with some confidence that the historical life of Jesus was lived roughly between the years 4 BCE and $30 \mathrm{CE}$ (Ehrman 2008). We can also date the writing of the gospels with relative accuracy between the years 70-100 CE. Two events in history help this dating process. The first one is that the year 70 was the time when Jerusalem fell to the Roman legions and was largely destroyed. This event appears, I am convinced, to be reflected in each of the gospels. On the other end of this dating process only John seems to be aware of the expulsion of the followers of Jesus from the Synagogues that occurred near the end of the $9^{\text {th }}$ decade of the Christian era. So no gospel appears earlier than $70 \mathrm{CE}$ and only John seems to be a $10^{\text {th }}$ decade work ${ }^{7}$. So playing with these various dates, the first bit of biblical factual reality emerges. There is a gap of some forty years between the end of Jesus' life and the writing of any gospel and all of the canonical gospels are completed by 100 CE. The years between 30-70 CE are a silent period, interrupted only by the writing of Paul, who tells us almost nothing about the Jesus of history. These forty years are the oral tunnel through which the memory of Jesus had to journey before the story of his life was committed to writing. Everything we are told in the gospels about Jesus must, therefore, have traveled by word of mouth for at least forty years, or over two - three generations before entering the gospels. Can any record of anything be thought of as literally accurate when set against that kind of oral history?

$7 \quad$ The Gospel according to Luke may be hard to date. Luke had moved far enough out of the Jewish orbit geographically and into the Gentile world that these two events may not have been important enough in Luke's work to have received notice. Luke strikes me as prior to $95 \mathrm{CE}$, no earlier than the late 80's. 
The second fact that needs to be faced is that all of the gospels were originally written in Greek, a language which neither Jesus nor his disciples spoke with any proficiency and which surely none of them was able to write. Everyone knows that there is no such thing as a perfect translation. Recognizing these realities does not destroy the integrity of the gospels, as the biblical literalists like to claim, but they do destroy the credibility of the literal claims that people continue to make for the gospels. Perhaps even more important these facts open the doors to a whole new approach to the Jesus story.

\section{THE SYNOPTIC GOSPELS AND THE SYNAGOGUE}

Once we have established the fact of a forty-year translation gap between the Jesus of history and the gospels then we are driven to ask where did the story of Jesus live and by what means was it transmitted and translated during the oral period? The surviving material we have in the gospels is far too complete and complex to have been either a happenstance or a personal one-on-one transmission. The only place to look for clues is in the gospels themselves, for surely the place where the story of Jesus was recalled and passed on for a minimum of forty years would leave its marks on the contents of these gospels. So by using primarily the earliest gospel Mark as my frame of reference, but going briefly into the works that are dependent on Mark, (namely Matthew and Luke), let me search for clues to the oral period.

\subsection{The gospel of Mark}

The opening line of Mark is itself quite revelatory: "The beginning of the gospel of Jesus Christ, as it is written in the prophets" ${ }^{8}$. Then Mark begins his Jesus narrative with quotes from both Malachi and Isaiah. Embrace what that means. When the first sentence of the earliest gospel is written, the obvious thing that confronts us is that the Hebrew Scriptures have already been wrapped around Jesus. There is only one place where this could have occurred and that is in the synagogue ${ }^{9}$. What leads me to that assertion? It is quite simple. The synagogue was the only place in the first century where the

8 Some ancient manuscripts add the phrase "The Son of God" after Jesus Christ, but this appears to be an early copyist's addition.

$9 \quad$ My study on this issue has been shaped in large measure by the English biblical scholar Michael Donald Goulder, expressly in his book Midrash and Lection in Matthew. 
scriptures were ever heard, read, taught, transmitted or interpreted. Individuals did not own personal copies of the sacred writings. Books were rare commodities. There was no Gideon Society to put a Bible into one's hotel room. The scriptures of the Jews were the property of the Jewish community. They were far too expensive to produce for individual use since they had to be hand-copied by professional scribes on scrolls of expensive vellum or parchment. This interpretative pattern of wrapping the Jesus story around the Hebrew Scriptures is present on almost every verse of this gospel. So we continue to read Mark and watch the evidence mount.

Mark next introduces John the Baptist (Mk 1:2-8), but the John that Mark portrays is not a person of history at all. He is an interpreted icon always transformed to fit into the developing interpretation of Jesus as messiah. John the Baptist fulfills Jewish messianic expectations. If Jesus is to be understood by Mark's Jewish readers as the promised messiah, which is certainly Mark's intention, then according to Jewish tradition, Elijah must precede the messiah to prepare the way. Mark has clearly turned John the Baptist into that Elijah. How do we know this? Because Mark locates him in the wilderness, which was Elijah's location (1 Ki 14). Mark clothes John in camel's hair with a leather belt around his waist, which was Elijah's clothing. Mark portrays John as eating a diet of locusts and wild honey, which was Elijah's diet. All of these references are direct quotes out of the Hebrew Scriptures, the content of which Mark's Jewish readers would know full well. Those readers, therefore, know that Mark was not presenting a literal eye witness report of either John the Baptist or Jesus; he was rather painting an interpretative portrait.

Following Jesus' baptism by this Elijah figure, Mark next relates a series of miracle stories portraying Jesus as a cleansing and healing agent of God (Mk 1:21-2:12). These episodes come in rapid succession and introduce Jesus as a miracle worker. Is that history? I can find no suggestion prior to the writing of Mark in the $8^{\text {th }}$ decade that miracles were ever associated with the memory of Jesus. Certainly there are no miracles in the writings of Paul. Even for those who claim that either the Q Document and/or the Gospel of Thomas can be dated prior to Mark — and I am not one of them agree that there are no miraculous accounts in either source.

We then look at the Hebrew Scriptures as a whole for examples of other miracle stories. Most people do not realize just how limited 
these presumably supernatural events are in the sacred text. Miracles in the Bible are generally limited to three cycles of stories. In the Moses/Joshua cycle there are miracle stories, some bordering on magic tricks, but all of them can be included in what we would call nature miracles. In the Elijah/Elisha cycle of stories, there are again nature miracles, but added here are two accounts of the prophets having the power to raise the dead and one story in which Elisha heals a foreigner of his leprosy. The only other place in the Bible where miracles seem to be commonplace is in the Jesus/Disciples of Jesus cycle of stories. Here we have nature miracles, raising of the dead miracles and a series of healing miracles all attributed to Jesus, and later in the book of Acts to the disciples who act in Jesus' name.

When these gospel miracle stories that are attached to Jesus are analyzed and compared with the Moses and Elijah narratives, a remarkable similarity becomes obvious. Jesus' nature miracles, which involve his power over wind and water and his feeding the multitudes with five loaves in the wilderness, all look like expanded Moses stories being retold about Jesus. We need to be aware that a major messianic image in the Jewish tradition was that messiah would be a new Moses. As the nature miracle stories are wrapped around Jesus by Mark, this is the claim that Mark is making. Mark is portraying Jesus as the new Moses. Jesus feeding the multitudes in the wilderness with limited resources is a retelling of the story of Moses feeding the multitudes in the wilderness with heavenly manna. Mark even signals to his readers that this narrative is not to be literalized for he tells this story twice: once on the Jewish side of the lake where 5000 are fed with five loaves and twelve baskets of fragments are gathered afterward (Mk 6:35-44) and the second on the Gentile side of the lake where 4000 are fed with seven loaves and seven baskets of fragments are gathered up later (Mk 8:1-10). Is this really a miracle story or is Mark saying that the meaning of Jesus as sufficient to feed the hunger of both the Jews and the Gentiles with much to spare?

Mark has Jesus raise one person from the dead, a child, the daughter of Jairus, a ruler of the synagogue (Mk 5:21-43). When this story was analyzed closely, it appears to be little more than the account of Elisha raising a child from the dead now being retold about Jesus.

Isaiah declares that when the Kingdom of God dawns, the blind will see, the deaf hear, the lame leap and the mute sing (Is 
35:3-6). When Mark says that Jesus did all of these things he is proclaiming that in Jesus, the Kingdom of God has dawned in human history. One of those healing stories makes this symbolic nature quite clear. Mark says that Jesus restored the sight of the blind man from Bethsaida in stages (Mk 8:22-26). Mark locates this narrative in his gospel adjacent to Peter's confession at Caesarea Philippi in which Peter acknowledges Jesus as "the Christ" but then reveals that he has no idea what being the messiah meant (Mk 8:2730). Peter's blindness was not removed, except in stages. When we add to this analysis the note that Peter hailed from Bethsaida, we begin to recognize that a literal reading of this story was the last thing that Mark had in mind. Mark was interpreting Jesus in all of the miracle stories as the new Moses, the new Elijah or as the one in whom the Kingdom of God was dawning. Only those of us who, as Gentiles, are unfamiliar with the Jewish Scriptures, would think that Mark was describing literal history.

Next, we look at the climax to Mark's gospel, that narrative we call "the Passion of Jesus". It is found between Mark 14:17 and 15:47. Examine it closely. Most people feel that when they arrive at this part of the Jesus story they are on firm, even historical, ground. This is a familiar narrative. It is read in our churches every Holy Week. We have been taught to think of it as history, as eye witness reporting. Mark clearly knew, however, that this too was not history as I shall try to demonstrate. When we look at this story closely, the first thing we discover is that it is written in eight three-hour segments that are designed to carry us, the readers, from sundown on Thursday to sundown of Friday, reflecting, I believe, a 24 hour vigil format. The eight segments are easy to identify, five of them have the time markers stated overtly. The other three rise from our knowledge of Jewish traditions.

The first time designation comes in the opening verse of the segment. "When it was evening" (Mk 14:17) which means it is approximately 6:00 p m. In a world without electricity evening began at sundown and people ate the evening meal in the remaining moments of twilight. In this segment the meal, which was clearly in Mark's mind a Passover meal, is discussed. The Jewish Passover lasted approximately three hours. It included not just the meal itself with its symbols of unleavened bread and bitter herbs, but a time for fun and games and the ritualistic rehearsal of their history which comes as a response to the questions of the youngest male child to 
the oldest family patriarch: "Father, why is this night different from all other nights?" The Passover concluded with the singing of a hymn. These closing moments of that liturgical meal are stated overtly in Mark's story when he writes that "following the singing of a hymn” Jesus and his disciples go out into the night (Mk 14:17-26). It is therefore now 9:00 $\mathrm{p} \mathrm{m}$.

The second segment of this vigil occurs in Gethsemane where Jesus takes Peter, James and John with him for a time of prayer, instructing them to stay awake and watchful while He went further to be alone. These disciples, however, could not watch with Him without falling asleep, whether it was one hour, two hours or three hours. Thus the second watch in this liturgical drama concludes at midnight (Mk 14:27-42).

This timing thus enables Mark to stage the act of betrayal at midnight. This act is regarded by Mark as the darkest deed in human history, which means that it should occur at the darkest hour of the night. That was good drama, but hardly history. So the betrayal becomes a midnight event and is followed by the arrest of Jesus at which time Mark notes "all of them forsook him and fled" (Mk 14:50). Jesus is then taken before the High Priest and the Sanhedrin to be interrogated. In this segment Jesus refers to his body as the Temple which will be destroyed. By the time of Mark's writing, I am convinced, Jerusalem has already fallen to the Romans and the Temple has been destroyed. Jesus' disciples have begun to refer to his body as the new Temple. It is the new place where God and human life come together. At the trial Jesus is found guilty of blasphemy and is abused by his guards (Mk 14:43-65). The third segment of the Vigil is over. It is now 3:00 a m.

The watch of the night between 3:00 a $\mathrm{m}$ and 6:00 a m was known as "cockcrow". Into this three hour segment, Mark has placed the story of Peter's denial, which is to occur before the crowing of the cock, announcing the arrival of dawn. In this three hour segment, Peter denies Jesus three times, once, presumably, for each hour. This episode carries us to dawn (Mk 14:66-72).

Right on cue, Mark announces the arrival of morning with the words, "As soon as it was morning" (Mk 15:1) which means that it is approximately 6:00 a m. In this segment, Mark is going to describe the trial before Pilate and Jesus' condemnation. Here we have Pilate's interrogation of Jesus, his attempt to find a way to 
release Jesus and the introduction of Barabbas. Jesus is scourged, mocked and prepared for crucifixion. The journey to Calvary is completed with a man named Simon of Cyrene carrying his cross. The fifth watch of the night is complete (Mk 15:1-24). Mark notes this transition in time once more by saying that, "It was the third hour," or 9:00 a m “when they crucified Him” (Mk 15:25).

In this segment the thieves who are on each side of Him are introduced by Mark, but they play no role. In Matthew both join in reviling Jesus. In Luke one of them is penitent. In John they are once again just part of the scenery. The crowd also carries out a dialogue with this victim from below the cross. Once more, Mark reveals his 24 hour vigil format for he announces, (Mk 15:33) "When it was noon” to begin the next segment.

Here he introduces the apocalyptic darkness, as all of creation mourns the suffering and death of the "Light of the world!" The darkness lasts, not surprisingly, for three hours carrying us to 3:00 $\mathrm{p}$ $\mathrm{m}$ when the cry of dereliction is uttered, "My God, my God, why hast thou forsaken me?” (Ps 22:2) and with one more loud cry, the content of which Mark does not give us, Jesus dies. His death is then accompanied by dramatic signs. The veil in the Temple is split from top to bottom. This veil separated the Holy of Holies in which God was assumed to live and the Holy Place in which the people can gather. Only the High Priest could enter the Holy of Holies and he only once a year at Yom Kippur and then only after elaborate cleansing rituals. Then Mark designates a Gentile soldier to interpret Jesus as God's son. It is at this moment that the women, who have followed Him from Galilee, now become visible (Mk 15:33-41).

The last segment in this format to complete the 24 hour vigil carries us from 3:00 $\mathrm{p} \mathrm{m}$ to 6:00 $\mathrm{p} \mathrm{m}$, at which time presumably the sun went down and the Sabbath was declared to have begun. The body of Jesus was removed from the cross. In this segment Joseph of Arimathea was introduced. The burial was arranged in Joseph's tomb and Jesus' body was wrapped in a linen cloth, laid in the tomb, which was secured with a rock or boulder to cover its opening, and the women watch where he is laid. It was now 6:00 p $\mathrm{m}$ and the eight segments of this 24 hour vigil ceremony are complete. If Mark were writing history why, we might inquire, was this narrative divided into eight segments of three hours each, neatly noted as if it were a liturgical act? Mark's original intention looks far more like a vigil format to guide worship than it does like history. It is not 
focused on how Jesus died, but on who it was who died and what his death meant. It is interpretive, not historical.

Beyond that an analysis of the content of this drama reveals quite overtly that it is not based on eye witness accounts. Mark has already told us that when Jesus was arrested, all not some - but all of his disciples forsook Him and fled (Mk 14:50). Earlier Jesus has even offered us a scriptural justification for their desertion, citing Zechariah's text (Mk 14:27) that when one strikes the shepherd, the sheep will flee (Zch 13:7). One does not go to this length to excuse behavior that never happened, so I surmise that the apostolic desertion by Jesus' disciples was indeed a fact remembered and needing to be explained by the Christian community. If that is true, as I believe it is, we need to come to an emotional acceptance of what is surely a shameful and embarrassing history, namely that Jesus died alone. No one was there to watch, to offer comfort or to record the story. It was not, therefore, possible for anyone to tell what Jesus said to the soldiers, to the Sanhedrin, to Pilate, to his tormentors or to the thieves, so all of this is a created narrative. Perhaps Mark was the creator of this passion story or perhaps it was the gift of the community of believers for whom Mark wrote. In either case these words represented not objective descriptions of an historical occurrence, but a liturgical reenactment by the second and third generations of Christians to enable them to recall and even to relive in a vigil format the death of Jesus and its meaning through which, they proclaimed, salvation has been procured. Mark based his narrative not on eye witness reports for there were no eye witnesses, but on texts from the Hebrew Scriptures, primarily the words of Psalm 22 and Isaiah 53. The phrases used in both of these Hebrew sources and in Mark's story of the Passion of Jesus are almost identical, revealing Mark's heavy dependency on these sources. One only has to read Mark's story of the Passion and those Hebrew narratives together for this to become obvious.

From Psalm 22, Mark got these parts of his Passion narrative: The cry of dereliction, "My God, my God, why have you forsaken me?," the content of the conversations between Jesus and the crowd, the story of the soldiers dividing Jesus' garments and rolling dice for what was called "his vesture", the note of thirst and the first hint that none of his bones would be broken. All of these elements are present in this psalm. 
From Isaiah 53, Mark got the portrait of Jesus as the one who was silent before his tormentors, and the idea that his suffering served a redemptive purpose: it was for us that He suffered. The thieves who were supposedly crucified with him were a dramatic fulfilling of that Isaiah 53 note that he was to be "numbered among the transgressors". The story of Joseph, the tomb and Jesus' burial was Mark's way of giving narrative form to Isaiah's words that the suffering servant would "make his grave with a rich man”.

There was a time in Christian history when we accounted for the close connection between Psalm 22 and Isaiah 53 and Mark's passion narrative by asserting that Jesus just fulfilled these prophetic utterances in a quite literal way. Today we know that it was exactly the other way around. The Hebrew Scriptures were opened when the Jesus story was being written and the gospel writers simply wrote their story in such a way as to make Jesus' life conform to these scriptural images.

From the opening line in the first gospel to its dramatic closing story, Mark has simply wrapped the story of Jesus inside the Jewish Scriptures. It was a quite intentional, self-conscious action. From these indisputable facts we realize that the oral period of Christian history was located very specifically in the synagogue. That was the only place in which these scriptures existed and the only place in which they were read. That can be the only place, therefore, in which the story of Jesus intertwined with the Hebrew Scriptures. As the scriptures of the Jews were read in the synagogue, the memory of Jesus was recalled and interpreted Sabbath by Sabbath, year by year, for a minimum of forty years. This was the oral period and lasted until the narrative reached written form.

\subsection{The gospel of Matthew}

The second gospel writer Matthew built his story largely on the work of Mark, but because of the traditional Jewish orientation of Matthew's congregation, he emphasized the way Jesus lived out a magnified Moses pattern. That is why Matthew included in his birth narrative the story of wicked King Herod destroying the Jewish boy babies of Bethlehem in his attempt to rid the world of God's promised deliverer. Matthew's Jewish audience would have recognized that as a Moses story for when Moses was born, a wicked king named Pharaoh also destroyed Jewish boy babies in an attempt to rid the world of God's promised deliverer (Ex 1:8-2:10). 
Matthew goes on to adapt Mark's story of Jesus' baptism so that it reflected the Moses experience of the Red Sea. Moses split the waters of the Red Sea while Jesus split the heavenly waters. Then Matthew expanded Mark's temptation story so that Jesus' forty days in the wilderness paralleled Moses' forty years in the wilderness. He made the three critical moments that Moses faced, the shortage of food (Ex 16:1-21), putting God to the test by striking the rock at Meribah (Ex 17:1-7) and the episode in which the people made a golden calf for their worship (Ex 32:1-35), into the content of Jesus' three temptations. Jesus also faced the shortage of food - "Turn these stones into bread, Jesus". Jesus also was also urged to put God to the test - "Cast yourself off the temple, Jesus". Jesus was tempted to worship something other than God - "Bow down before me, Jesus". Matthew alone portrays Jesus as preaching the Sermon on the Mount (Mt 5-7). He modeled this sermon after the form of Psalm 119, the psalm dedicated to the beauty and wonder of the law and designed to be used in synagogue worship at the Festival of Shavuot, when the people of Israel recalled liturgically the time at Mount Sinai when Moses received the Torah. It is obvious that Matthew's gospel, no less than Mark's, is an interpretative piece of work not to be read literally.

\subsection{The gospel of Luke}

Luke, the third gospel to be written, also based his work on that of Mark. He was not as rigid in that borrowing as Matthew had been, drawing only about half of Mark's words into his gospel, while Matthew had drawn about ninety per cent of Mark's words into his gospel. However, Luke did not use Moses, the giver of the law, as his chief image for Jesus. His congregation was far more cosmopolitan than Matthew's and, therefore, less traditionally Jewish in its orientation. It was made up of dispersed Jews and converting Gentiles. The work of the outward looking Jewish prophets, especially Elijah, not the inward looking Jewish lawgiver, Moses, was thus his model for interpreting Jesus.

Luke began to make his perspective clear in the genealogy of Jesus (Lk 3:23-38). He went back to Adam, the father of the human race, as his starting point not just to Abraham, the father of the Jewish nation. Luke next refused to identify John the Baptist with Elijah. His intention was to portray Jesus as the new and greater Elijah. Luke alone told the story of Jesus healing the ten lepers, one of whom was a foreigner, a Samaritan (Lk 17:11-19). It was a story 
patterned on the story of Elisha, Elijah's successor, who healed a foreigner, Namaan, of his leprosy (2 Ki 5). Luke alone had Jesus raise a widow's only son from the dead in the village of Nain. That narrative was also modeled on an Elisha story since that prophet also raised the only son of a widow from the dead (2 Ki 2:1-8).

The climax of Luke's interpretive genius, however, came when he told the story of Jesus' ascension into heaven and his pouring out of the Holy Spirit at Pentecost. It is little more than a magnified Elijah story as a careful reading of Elijah's ascent into heaven and the gift of his spirit to his disciple Elisha makes abundantly clear (2Ki 2:1-8).

\section{RESCUING THE BIBLE FROM FUNDAMENTALISTS}

None of the synoptic gospels, not Mark, Matthew or Luke, was written to be read literally. None is recording literal history. All of these gospel authors knew that. Today when we read these narratives literally, we cannot help but distort them dramatically. Indeed to literalize the Jesus story is to make it all but unbelievable.

Christians need to stop being intimidated by biblical literalists. We need to rescue the Bible from the distorting fundamentalist mentality. That is step number one in the new reformation. The question we need to ask of the gospels is not, "Did this really happen?" - that is the fundamentalist's question. We ask, "What was there about Jesus that caused the gospel writers to wrap Him in the Hebrew Scriptures," as their source of fulfillment. That question will lead us not into a debate on the accuracy of these descriptions, but into the Jesus experience that those biblical descriptions sought to illustrate.

The final question we need to face is how was it possible for these gospel narratives to come to the place where people now seem to think that reading them literally was the only proper way to read them? The fact is that the gospels were written by Jews for Jews and in the context of synagogue worship where they were all familiar with the Hebrew Scriptures. By the year 125 CE, however, there were few Jews left in the Jesus movement. By 140 CE Marcion was raising his anti-Semitic rhetoric. From that time on Christianity was predominantly a Gentile movement. It continued to be that for almost 1900 years of Christian history. During that time the only people who read the gospels, interpreted the gospels and even wrote commentaries on the gospels were Gentiles. They were not only 
ignorant of the Jewish scriptures that were the interpretive clues to understanding the gospels, but they were deeply anti-Semitic and thus prejudiced against learning anything about the Jewish roots of the gospels. So without Jewish eyes or understanding, the Gentile readers proceeded to literalize the stories. It was these uninformed Gentiles who decided the gospels should be read as literal history. They are the ones who created fundamentalism, which is essentially a Gentile heresy. They are the ones who led Christianity into what I call "the Gentile captivity" of the gospels. In that captivity we have lived for most of the last 2000 years.

The battle by biblical scholars in the United States and South Africa today against biblical fundamentalism is in fact a battle to restore the gospels to what the gospel writers intended them to be all along, interpretive portraits of the experience of God that our ancestors in faith believed they experienced.

"God was in Christ" was Paul's way of asserting that the meaning of the Jesus experience was a God presence. The story of the Holy Spirit filling Jesus at the time of his baptism was Mark's way of asserting that the meaning of the Jesus experience was a God presence. The diverse stories of the virginal conception of Jesus told by Matthew and Luke were these gospel writers' ways of asserting that the meaning of the Jesus experience was a God presence. The account of the Word being made flesh was John's way of asserting that the meaning of the Jesus experience was a God experience.

We will never understand the gospels if we read them literally. Our task is to go through and beyond the literal words of these ancient texts until we touch the experience that made these words necessary. There and there alone will the power of the gospels be fully and finally understood ${ }^{10}$.

\section{Consulted literature}

Bonhoeffer, D 1971. Letters and Papers from Prison. London: SCM.

Ehrman, B D 2008. The New Testament: A Historical Introduction to the Early Christian Writings. Now York: Oxford University Press.

10 This lecture is drawn substantially out of my book Jesus for the NonReligious (Spong 2007), now out in paperback from HarperCollins. There the reader will find a fuller treatment and an expanded documentation of the ideas presented here. 
Goulder, M D 1974. Midrash and Lection in Matthew: The Speaker's lectures in Biblical Studies, 1969-1971. London: SPCK.

Olson, R G 2004. Science \& Religion, 1450-1900: From Copernicus to Darwin. Baltimore: John Hopkins University Press.

Ratzinger, J (Pope Benedict XVI) 2007. Jesus of Nazareth: From baptism in the Jordan to the transfiguration.New York: Doubleday.

Scholder, K 1990. The Birth of Modern Critical Theology: Origins and Problems of Biblical Criticism in the Seventeenth Century. London: SCM.

Spong, J S 2007. Jesus for the Non-Religious: Recovering the Divine at the Heart of the Human. San Francisco: HarperCollins. 